\title{
ХІРУРГІЯ
}

(C) П. Берек, I.І. Кополовець, В.І. Русин, М. Франковічова, 2019

УДК 616.132.14+616.133]-004.6-089.87:616.831-005.1:616.89-008.45/.48

\section{Оцінка якості життя та когнітивних порушень у пацієнтів із атеросклеротичним ураженням екстракраніальних артерій}

\author{
П. Берек ${ }^{1}$, І.І. Кополовець ${ }^{1,2}$, В.І. Русин ${ }^{2}$, М. Франковічова ${ }^{1}$ \\ i.kopolovets@gmail.com \\ ${ }^{I}$ Клініка судинної хірургії, Східно-Словацький інститут сериево-судинних хвороб, університет \\ П.Й. Шафарика, медичний факультет, Кочиие, Словаиька Республіка, \\ ${ }^{2}$ Ужггородський наџіональний університет, медичний факультет, кафедра хірургічних хвороб, \\ Ужггород
}

\section{Реферат}

Вступ. Когнітивні порушення характерні для пацієнтів як із симптоматичним, так і асимптоматичним стенозом внутрішньої сонної артерії (ВСА), а одним із важливих критеріїв ефективності лікування є оцінка якості життя.

Мета дослідження. Оцінити якість життя та когнітивні порушення у пацієнтів із ураженням екстракраніальних артерій.

Матеріали та методи. У дослідженні проаналізовано 85 хворих: I група - 30 хворих із симптоматичним стенозом ВСА; II група - 40 пацієнтів із асимптоматичним стенозом ВСА; III група - 15 хворих із синдромом підключично-хребтового обкрадання (СПХО), у яких перед операцією та через 6 місяців після артеріальної реконструкції вивчено якість життя та порушення когнітивних функцій.

Результати досліджень та їх обговорення. За шкалою MMSE перед операцією у всіх трьох групах виявлено когнітивні порушення різного ступеня вираженості. У пацієнтів із симптоматичним стенозом ВСА когнітивні порушення помірного ступеня вираженості були статистично достовірні по відношенню до асимптоматичних пацієнтів. При порівнянні параметрів якості життя у післяопераційному періоді статистично достовірними $(\mathrm{p}<0,05)$ були показники у пацієнтів із симптоматичним стенозом ВСА та у хворих із СПХО. Якщо у пацієнтів із синдромом обкрадання позитивні зміни наступали через реваскуляризацію ураженої артерії, що в свою чергу призводило до ліквідації синдрому обкрадання головного мозку, то у пацієнтів із симптоматичним стенозом ВСА покращення якості життя відбувалось в першу чергу через регресію неврологічного дефіциту. Психо-емоційний компонент якості життя як в доопераційному, так і в після операційному періоді був найвищим у хворих із асимптоматичним стенозом ВСА.

Висновки. При оцінці когнітивних функцій у післяопераційному періоді у кожній обстежуваній групі спостерігалось когнітивне покращення, але без статистичної достовірності. Достовірне покращення якості життя спостерігалось у пацієнтів із симптоматичним стенозом ВСА та СПХО.

Ключові слова: атеросклероз, сонні артерії, каротидна ендартеректомія, інсульт, когнітивні порушення, якість життя.

Assessment of quality of life and cognitive impairments in patients with atherosclerotic lesions of extracranial arteries P. Berek ${ }^{1}$, I.I. Kopolovets ${ }^{1,2}$, V.I. Rusyn ${ }^{2}$,M. Frankovičová ${ }^{1}$

Clinicof VascularSurgery, East Slovak Institute of Cardiovascular Diseases (VUSCH), Faculty of Medicine, Pavol Jozef

Šafárik University, Košice, Slovak Republic

Uzhhorod National University, Medical Faculty, Department of Surgical Diseases, Uzhhorod ${ }^{2}$

\section{Abstract}

Introduction. Cognitive impairments are typical for the patients with both symptomatic and asymptomatic stenosis of the internal carotid artery (ICA), and quality of life assessment is one of important criteria for evaluating treatment effectiveness.

The aim of the research was to assess quality of life and cognitive impairments in the patients with extracranial arterial lesions.

Materials and methods. In the study, 85 patients were analyzed: Group I included 30 patients with symptomatic ICA stenosis; Group II comprised 40 patients with asymptomatic ICA stenosis; Group III included 15 patients with vertebralsubclavian steal syndrome (VSSS) whose quality of life and cognitive impairments were studied before surgery and 6 months after arterial reconstruction.

Results. According to the Mini-Mental State Examination (MMSE) before surgery, cognitive impairments of various degree of severity were observed in all the groups. In the patients with symptomatic ICA stenosis, mild cognitive impairments 
were statistically significant as compared to asymptomatic patients. When comparing quality of life parameters in the postoperative period, statistically significant $(\mathrm{p}<0.05)$ indicators were found in the patients with symptomatic ICA stenosis and those with VSSS.In the patients with steal syndrome, positive changes occurred due to revascularization of the affected artery, that, in its turn, led to the elimination of steal syndrome, while in the patients with symptomatic ICA stenosis, the improvement of life of quality was primarily due to the regression of neurologic deficit. The psycho-emotional component of quality of life was the highest in the patients with asymptomatic ICA stenosis both in the preoperative and postoperative period.

Conclusions. When assessing cognitive functions in the postoperative period, in each studied group, there was observed cognitive improvement without statistical significance. Reliable improvement of quality of life was observed in the patients with symptomatic stenosis of the internal carotid artery and vertebral-subclavian steal syndrome

Key words: atherosclerosis, carotid arteries; carotid endarterectomy, stroke, cognitive impairments, quality of life

Вступ. Більше 35\% хворих, які перенесли гостре порушення мозкового кровообігу (ГПМК), мають ознаки когнітивних порушень [1]. Треба відзначити, що когнітивні порушення характерні й для пацієнтів із асимптоматичним стенозом ВСА, які $є$ проявом хронічної ішемії головного мозку [2]. Окрім когнітивних порушень, важливим критерієм є якість життя. Специфіка поняття якості життя полягає в тому, що включає в себе як об'єктивні, так і суб'єктивні критерії, що характеризують фізичний, психічний і соціальний добробут [3]. У літературних джерелах доступні роботи, які оцінюють вплив каротидної ендартеректомії на якість життя та зміну когнітивних порушень [4]. Деякі автори ефективність каротидної ендартеректомії оцінюють не тільки як хірургічну профілактику ГПМК, але і як профілактику прогресії хронічної ішемії головного мозку [5]. Особливо це стосується осіб похилого віку. Тому корекція когнітивних порушень має важливе значення в покращенні якості життя.

Мета дослідження. Оцінити якість життя та когнітивні порушення у пацієнтів після каротидної ендартеректоміі.

Матеріали та методи. У дослідженні включено 85 хворих (30 хворих із симптоматичним стенозом внутрішньої сонної артерії (BCA) - I група, 40 пацієнтів із асимптоматичним стенозом ВСА - II група; 15 хворих із синдромом підключичнохребтового обкрадання (СПХО) - III група), яким перед операцією та через 6 місяців після артеріальної реконструкції вивчено якість життя (ЯЖ) та порушення когнітивних функцій. Статистичної відмінності за віком та статтю у представлених групах не було. Усім пацієнтам із стенозом ВСА (I-II група) була виконана еверсійна каротидна ендартеректомія під загальним знеболенням. У 7 (46,7\%) пацієнтів із СПХО виконано ендоваскулярну реваскуляризацію, а у $8(53,3 \%)$ пацієнтів артеріальну реконструкцію (транспозиція лівої підключичної артерії - 5 хворих; соннопідключичне протезування - 4 пацієнти).

Оцінку ЯЖ проведено за допомогою загальних анкет-опитування MOS SF - 3, які відносяться до неспецифічних опитувальників для оцінки якості життя. Анкета включає 8 шкал, де є 36 запитань, що становлять фізичні та психологічні компоненти здоров'я: фізичне функціонування, рольова діяльність, тілесний біль, загальне здоров'я, життєздатність, соціальне функціонування, емоційний стан і психічне здоров'я. Оцінювали отримані результати за такими критеріями: якість життя незадовільна - менше 25 балів; задовільна - від 25 до 45 балів; хороша понад 45 балів.

Когнітивні порушення оцінювались за шкалою MMSE. Пацієнти відповідали на запитання анкети, яка їм була запропонована до та після операції. Відповіді на питання оцінювали за номінальною шкалою від 0 до 5, а потім виводили загальний показник для кожного пункту за формулою: обчислене значення = (реальне значення показника мінімально можливе значення показника): можливий діапазон значень х 100.

Статистична обробка виконувалась в програмі “Microsoft Excel 2013". Достовірність одержаних результатів оцінювали за допомогою непараметричного U-критерію Манна-Уітні.

Результати досліджень та їх обговорення. Одним 3 основних клінічних проявів хронічної ішемії головного мозку є когнітивні порушення, що виникають як після інсульту, так і при дисциркуляторній енцефалопатії [6]. У роботі ми проаналізували когнітивні функції та якість життя у пацієнтів із атеросклерозом брахіоцефальних артерій перед операцією та після артеріальної реконструкції. Необхідність у оцінці ЯЖ після лікування полягає в тому, що комфорт i відчуття якості життя кожного окремого пацієнта залежить не настільки від об'єктивної оцінки лікаря або оточуючих, а в першу чергу від індивідуальних відчуттів задоволення кожної людини.

Після аналізу результатів опитування ми отримали такі результати (табл. 1). Перед операцією фізичний компонент здоров'я був найнижчим у пацієнтів із СПХО $(38,4 \%)$ та симптоматичним стенозом ВСА (41,4 \%), а найвищим у пацієнтів із асимптоматичним стенозом ВСА (47,2\%). У післяопераційному періоді через 6 місяців достовірна відмінність $(\mathrm{p}<0,05)$ фізичних характеристик виявлена у хворих із СПХО. 
Показники якості життя у хворих за даними опитування

\begin{tabular}{|c|c|c|c|c|c|c|}
\hline \multirow{2}{*}{ Характеристика } & \multicolumn{2}{|c|}{ I група $(\mathrm{n}=30)$} & \multicolumn{2}{|c|}{ II група $(\mathrm{n}=40)$} & \multicolumn{2}{|c|}{ III група $(\mathrm{n}=15)$} \\
\hline & A & Б & A & Б & A & Б \\
\hline Фізична функція & $39,3 \pm 8,2$ & $51,3 \pm 7,5^{*}$ & $52,3 \pm 11,2$ & $59,4 \pm 11,2$ & $38,7 \pm 12,6$ & $57,6 \pm 9,4^{*}$ \\
\hline Фізична роль & $41,5 \pm 6,7$ & $54,2 \pm 5,4$ & $45,2 \pm 12,7$ & $56,3 \pm 12,7$ & $39,2 \pm 14,7$ & $52,3 \pm 4,5^{*}$ \\
\hline Фізичний біль & $43,5 \pm 7,2$ & $56,3 \pm 8,4$ & $43,5 \pm 6,7$ & $47,8 \pm 9,2$ & $37,3 \pm 8,7$ & $49,5 \pm 4,8^{*}$ \\
\hline Загальне здоров’я & $39,6 \pm 5,8$ & $47,3 \pm 8,5$ & $52,4 \pm 9,5$ & $54,7 \pm 4,6$ & $36,3 \pm 9,2$ & $47,6 \pm 73$ \\
\hline Життєздатність & $37,5 \pm 9,2$ & $52,3 \pm 5,2 *$ & $51,3 \pm 12,5$ & $56,2 \pm 8,7$ & $43,2 \pm 12,5$ & $51,4 \pm 6,5$ \\
\hline Соціальна роль & $36,5 \pm 12,3$ & $42,2 \pm 7,5$ & $46,5 \pm 6,7$ & $51,2 \pm 5,4$ & $33,5 \pm 7,4$ & $42,6 \pm 58$ \\
\hline Емоційна роль & $34,6 \pm 7,2$ & $45,6 \pm 8,7$ & $45,3 \pm 7,2$ & $56,4 \pm 8,2$ & $35,1 \pm 6,2$ & $46,7 \pm 6,3$ \\
\hline Психічне здоров'я & $35,7 \pm 9,6$ & $46,6 \pm 6,2$ & $42,6 \pm 8,3$ & $49,7 \pm 5,2$ & $34,6 \pm 8,2$ & $42,5 \pm 8,7$ \\
\hline
\end{tabular}

Примітка: А - оцінка якості життя та когнітивних порушень до операції; Б - через 6 місяців після операції. Величини * представляють статистичну відмінність між окремими групами.

Загальне здоров'я (33) за суб'єктивною самооцінкою було найвищим $(52,4 \%)$ у пацієнтів із асимптоматичним стенозом ВСА (II група), а найнижчим (36,3\%) - у пацієнтів із СПХО (III група).

Психо-емоційний компонент якості життя як в доопераційному $(42,6 \%)$, так і в після операційному періоді $(49,7 \%)$ був найвищим у хворих із асимптоматичним стенозом ВСА, тоді як достовірна відмінність $(\mathrm{p}<0,05)$ психо-емоційного здоров'я у післяопераційному періоді виявлена тільки у хворих із СПХО.

При порівнянні параметрів ЯЖ у післяопераційному періоді статистично достовірними $(\mathrm{p}<0,05)$ були показники у пацієнтів із симптоматичним стенозом ВСА та у хворих із СПХО (рис. 1).

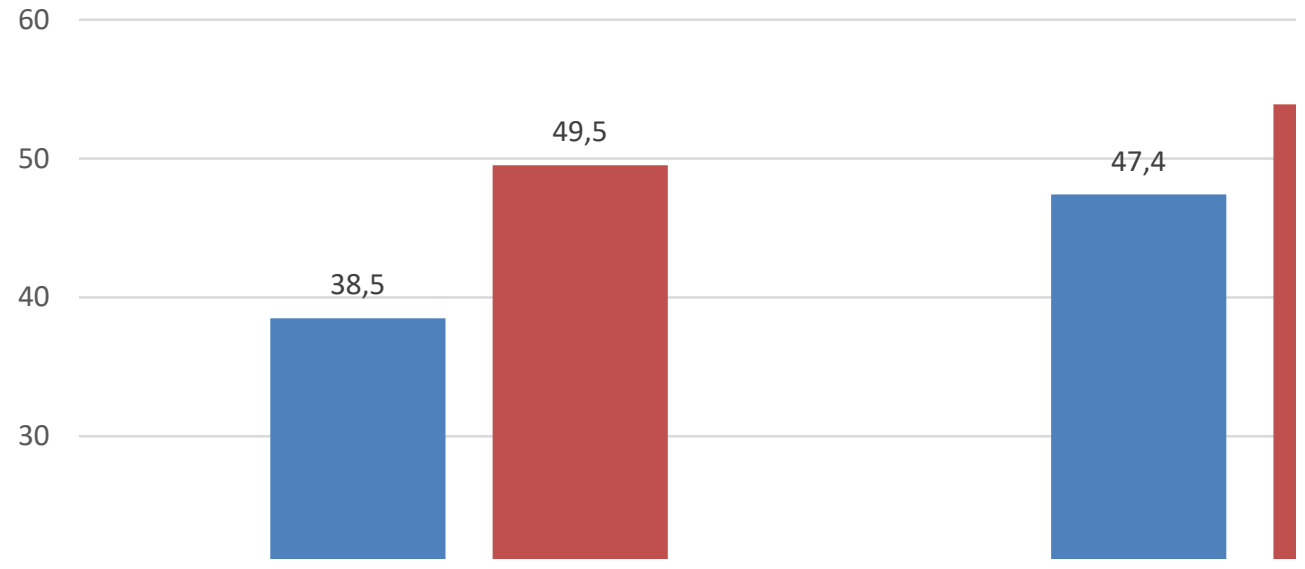

Рис. 1. Динаміка якості життя

Після обстеження пацієнтів за шкалою MMSE перед операцією у всіх трьох групах виявлено когнітивні порушення різного ступеня вираженості. У пацієнтів із симптоматичним стенозом ВСА когнітивні порушення помірного ступеня вираженості були статистично достовірні $(\mathrm{p}<0,05)$ по відношенню до асимптоматичних пацієнтів (табл. 2).
Тоді як у пацієнтів із асимптоматичним стенозом BCA когнітивні порушення легкого ступеня були статистично достовірні $(\mathrm{p}<0,05)$ як до асимптоматичних пацієнтів, так і до хворих із СПХО. У пацієнтів із СПХО спостерігались когнітивні порушення легкого та помірного ступенів важкості без статистичної достовірності ( $>>0,05)$. 
Оцінка когнітивних порушень за даними MMSE

\begin{tabular}{|l|c|c|c|c|c|c|}
\hline \multirow{2}{*}{ Характеристика } & \multicolumn{2}{|c|}{ І група $(\mathrm{n}=30)$} & \multicolumn{2}{c|}{ II група $(\mathrm{n}=40)$} & \multicolumn{2}{|c|}{ III група $(\mathrm{n}=15)$} \\
\cline { 2 - 7 } & $\mathrm{A}$ & Б & А & Б & А & Б \\
\hline Легкі КП & 2 & 4 & 10 & 19 & 3 & 6 \\
& $(6,7 \%)$ & $(13,3 \%)$ & $(25 \%)$ & $(47,5 \%$ & $(20 \%)$ & $(40 \%)$ \\
\hline Помірні КП & 14 & 15 & 25 & $17 \downarrow$ & 9 & $7 \downarrow$ \\
& $(46,7 \%)$ & $(50 \%)$ & $(62,5 \%)$ & $(42,5 \%)$ & $(60 \%)$ & $(46,7 \%)$ \\
\hline $\begin{array}{l}\text { Початкова стадія де- } \\
\text { менції }\end{array}$ & 13 & $10 \downarrow$ & 4 & $3 \downarrow$ & 3 & $2 \downarrow$ \\
\hline $\begin{array}{l}\text { Виражена стадія } \\
\text { деменції }\end{array}$ & $(43,3 \%)$ & $(33,3 \%)$ & $(10 \%)$ & $(7,5 \%)$ & $(20 \%)$ & $(13,3 \%)$ \\
\hline
\end{tabular}

Примітка: А - оцінка якості життя та когнітивних порушень до операції; Б - через 3 місяці після операції.

При оцінці когнітивних функцій (рис. 2) у кожній окремій групі спостерігалось когнітивне покращення, але без статистичної достовірності $(\mathrm{p}>0,05)$.

Однак треба відзначити, що у пацієнтів із симптоматичним стенозом ВСА, у яких було ішемічне вогнище головного мозку, як у передопераційному так і в післяопераційному періоді, явища початкової та вираженої деменції були статистично достовірними $(\mathrm{p}<0,05)$ відносно симптоматичних пацієнтів без ішемічного вогнища. Окрім того, виявлено статистично достовірне покращення $(\mathrm{p}<0,05)$ когнітивних функції у післяопераційному періоді у асимптоматичних пацієнтів із стенозом 85-95\% відносно хворих із стенозом ВСА 70-85\%.

Існує низка компенсаторних факторів регуляції мозкового кровообігу, які можуть компенсувати патофізіологічні механізми стенозу сонних артерій, що ускладнює оцінку його клінічної перебігу $[4,7]$. До таких факторів можна віднес- ти колатеральний кровообіг, Вілізієве коло та систему дрібних мозкових артерій, які здатні перерозподілити кровообіг на користь актуальних у даний момент зон мозку за рахунок метаболічних, гуморальних, рефлекторних, міогенних та інших механізмів $[8,9]$.

Виявлені когнітивні розлади можна пояснити зниженням перфузії мозку, а також можливою церебральною емболізацією з нестабільної атероматозної бляшки ВСА. Каротидна ендартеректомія не тільки виконує хірургічну профілактику емболізації із зони атеросклеротичної бляшки в ділянці біфуркації ВСА, але й збільшує гемодинамічний резерв головного мозку, що позитивно впливає на відновлення клініко-неврологічних і когнітивних функцій.

Отже, оцінюючи якість життя у післяопераційному періоді, зазначимо, що достовірне покращення $(\mathrm{p}<0,05)$ спостерігалось у пацієнтів із СПХО (III група).

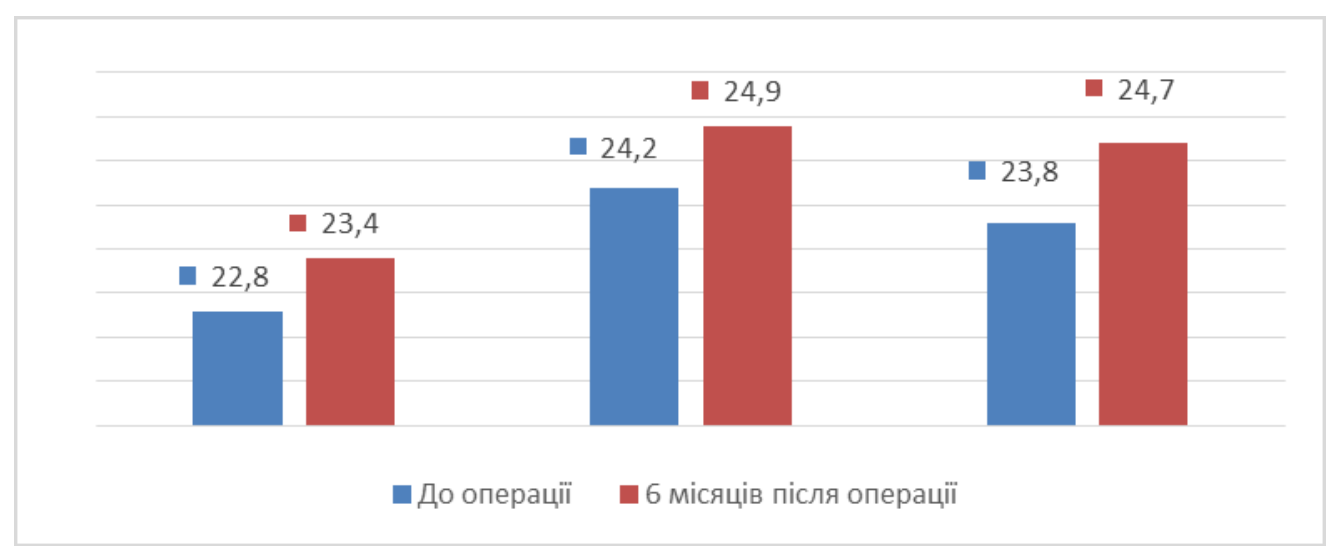

Рис. 2. Динаміка відновлення когнітивних функцій за даними MMSE

Вказані позитивні зміни можна обгрунтувати відновленням кровообігу через уражену артерію, що в свою чергу призвело до зникнення явищ ішемії верхньої кінцівки та ознак хронічної ішемії головного мозку через ліквідацію синдрому обкрадання із контрлатеральної ВСА. У симптоматичних пацієнтів у післяопераційному періоді теж спостерігалось достовірне покращення якості життя, але, на нашу думку, ці зміни в першу чергу пов'язані з реабілітацією та зменшенням неврологічного дефіциту. Найменші зміни щодо покращення якості життя спостерігались у пацієнтів із асимптоматичним стенозом ВСА.

Висновки. Достовірне покращення якості життя спостерігалось у пацієнтів із симптоматичним стенозом ВСА та СПХО. Якщо у пацієнтів із синдромами обкрадання позитивні зміни настали через реваскуляризацію ураженої артерії, що в свою 
чергу призводило до ліквідації синдрому обкрадання головного мозку, то у пацієнтів із симптоматичним стенозом ВСА покращення якості життя відбувалось в першу чергу через регресію невро- логічного дефіциту. При оцінці когнітивних функцій у кожній обстежуваній групі спостерігалось когнітивне покращення, але без статистичної достовірності.

Інформація про конфлікт інтересів. Автори заявляють про відсутність конфлікту інтересів при виконанні наукового дослідження та підготовці даної статті.

Інформація про фінансування. Автори гарантують, що вони не отримували жодних винагород у будь-якій формі, здатних вплинути на результати роботи.

Особистий внесок кожного автора у виконання роботи:

Берек П. - збирання та оброблення матеріалів.

Кополовець І. - формування дизайну дослідження та написання тексту.

Франковічова М. - аналіз отриманих даних.

\section{Список використаної літератури}

1. Bokeriya LA, AslanidiIP, Pyshkina LI, Serguladze TN, Darvish NA, Gvetadze IA, et al. Klinikonevrologicheskiei kognitivnye funkcii posle rekonstruktivnyh operacij pri stenozi ruyushchih porazheniyah brahiocefal'nyh arterij. Klinicheskaya fiziologiya krovoobrashcheniya. 2012; 4:30-8. [In Russian].

2. Kokorishvili MA. Vliyanie hirurgicheskogo lecheniya sonnyh arterij na kognitivnye funkciii kachestvo zhizniu pozhilyh pacientov starshe 70 let pri dvustoronnemgemo dinamicheski znachimom stenoze. Sovremennye problem nauki i obrazovaniya. 2016; 3:170-73. [In Russian].

3. Pospelova ML, Zajcev DE, Lepyohina AS, Efimcev AYU, Alekseeva TM, Trufanov GE. Kognitivnye narusheniyau pacientov s asimptomnymi karotidnymi stenozami bolee $70 \%$ - pokazanie k operativnomu lecheniyu? Sovremennye problemy nauki i obrazovaniya. 2019; 5:37-41. [In Russian].

4. Eskes GA, Lanctôt KL, Herrmann N, Lindsay P, Bayley M, Bouvier L,etal. Canadian Stroke Best Practice Recommendations: Mood, Cognition and Fatigue Following Strokepracticeguidelines, update 2015.Int J Stroke. 2015;10(7):1130-40. doi: 10.1111/ijs. 12557.

5. MacIntosh BJ, Edwards JD, Kang M. Post-stroke fatigue and depressive symptoms are differentially related to mobility and cognitive performance. Front Aging Neurosci. 2017; 9: 343-48.

6. Ismail Z, Elbayoumi H, Fischer CE. Prevalence of depression in patients with mildcognitive impairment: a systematic review and meta-analysis. JAMA Psychiatry. 2017;74: 58-67.

7. Lees R, Selvarajah J, Fenton C. Testaccuracy of cognitive screening tests for diagnosis of dementia and multi domain cognitive impairmentin stroke. Stroke. 2014;45:3008-18.

8. van Middelaar T, van Vught LA, van Gool WA. Blood pressure-lower in ginter ventions to preven tdementia: a systematic review and meta-analysis. J Hypertens. 2018; 36: 1780-87.

9. Sihotský V. Metod ouprvejvol'by pri stenóze karotidje CEA. Cesk Slov Neurol. 2016. 79/112(4):397-99. [In Slovakian].

Стаття надійшла до редакції: 22.01.2019 р. 